\title{
Zemahşerî Tefsirinde Emanet Âyeti
}

\author{
Yrd. Doç. Dr. Muhammed COŞKUN*
}

Öz: Ahzâb 33/72-73. âyetlerinde anlatılan "emanetin arz edilmesi” tefsir geleneğinde farklı şekillerde anlaşılmıştır. Önce Zeccâc (ö. 311/923), Matürîdî (ö. 333/944) ve Nehhâs (ö. 338/949) tarafından ifade edilen, daha sonra Zemahşerî (ö. 538/1143) tarafından delillendirilerek öne çıkarılan bir yorum, sonraki tefsir geleneği üzerinde çok etkili olmuş görünmektedir. Özellikle emanetin sunulması ( $\mathrm{arz}$ ) ve yüklenilmesine (haml) ilişkin ifadelerin mecaza hamledilmesi yaygın bir kabul görmüştür. Zemahşerînin yorumu, diğer yorumlar karşısında güçlü bir argümantasyona sahip olsa da kusursuz değildir. Bu yazıda âyetin tefsirindeki ihtilaf noktalarını özetledikten sonra Zemahșerînin yorumunda başarılı bir şekilde cevaplandırılmadığı düşünülebilecek soruları sormaya, meseleyi bu yönüyle tartışmaya çalışacağız.

Anahtar Kelimeler: Emânet, Akıl, İtaat, Zemahşerî. Delillendirme

\section{Zamakhsharîs Interpretation of the Qur'anic Verse of the "Offering the Trust"}

Abstract: The expression of "offering the Trust" stated in the Quran, chapter alAhzāb (The Joint Forces) 33/ 72-73, is interpreted divergently in the commentary tradition. One of the well-supported interpretation, which is first stated by Zajjàj (d. 311/923), Māturīdī (d. 333/944) and Nahhās (d. 338/949) and supported by evidence by Zamakhsharī, has been quite influential on the commentary tradition later on. Especially the relationship between the terms, "offering of the Trust" (ard) and "undertaking it" (haml) is most often taken as a metaphor. Although Zamakhsharîs interpretation has a stronger argumentation than other interpretations, it is not flawless. In this article I am going to discuss difficulties inherent in Zamakhsharīs interpretation. First, I am going to highlight issues of disagreement, then I am going to raise the questions that may not be satisfactorily answered by Zamakhsharîs interpretation.

Keywords: Offering of the Trust, Reason, al-Zamakhsharì, Argumentation

\section{I- Giriş}

33/Ahzâb Sûresinin 72. âyetinde emanet'in göklere, yere ve dağlara sunulduğu (arz), fakat onların bu emaneti yüklenmekten (haml) kaçındıkları (ibâ ve işfâk), bundan çekindikleri, buna karşılık insanın (el-İnsân) bu emaneti yüklendiği (haml) ifade edilmekte, devamında da insanın (el-İnsân) çok zalim (zalûm) ve çok cahil (cehûl) olduğu belirtilmektedir. Tefsir geleneğinde âyetteki emanet, sunma (arz) ve yüklenme (haml) kelimelerinin anlamı üzerinde olduğu gibi "çok zalim" (zalûm) ve "çok cahil” (cehûl) olarak nitelenen el-İnsân kelimesinin bütün insan cinsini içine alıp almadığı üzerinde de farklı yorumlar yapılmıştır. Bu farklılıklara bağlı olarak âyetin metin içindeki bağlamı ile birlikte bir bütün olarak nasıl

* Marmara Üniversitesi İlâhiyat Fakültesi Tefsir Anabilim Dalı Öğretim Üyesi.

E-posta: muhammed.coskun@marmara.edu.tr 
bir mesaj verdiği konusunda da farklı görüşler mevcuttur. Bu görüşler içerisinde görece daha dikkat çekici olanı başlangıçta Zeccâc (ö. 311/923), Matürîdî (ö. 333/944) ve Nehhâs (ö. 338/949) tarafından ifade edilen, daha sonra Zemahşerî (ö. 538/1143) tarafından gerekçelendirmesi yapılan yorumdur. Bu yorum diğerlerine kıyasla, metin içi bütünlüğe atıf yapması açısından, daha güçlü görünmekle beraber gerekçelendirmesinde tartışmaya açık noktalar bulunmaktadır. Bu sebeple biz bu yazıda ilgili ihtilaf noktalarını kısaca özetlemek dışında, emanetin ne anlama geldiği ve ayetin genel mesajının ne olduğu gibi hususları büyük ölçüde konu edinmeyip sadece Zemahşerî̀ye atfedilen yorumun gerekçelerini ve bu gerekçelerin yeterince güçlü olup olmadığını tartışacağız.

Âyetin tefsirindeki temel ihtilaf noktalarını; a) emanetin ne olduğu, b)emanetin yüklenilmesinin (hamlül-emâne) ne anlama geldiği, c) emanetin sunulmasının (arz) ve yüklenmesinin (haml) mecazi bir anlatım olup olmadığı şeklinde üç ana kategoride tasnif etmek mümkündür. Bu kategorilerden her birine ilişkin tercihler, diğerlerine ilişkin tercihlerde belirleyici rol oynamaktadır. Yine bu üç kategorideki görüşlerin âyete bütüncül bir mana verecek şekilde ve kendi içerisinde insicamlı olarak tanzim edilmesi de, görüş sahiplerinin farklı düzeylerde dikkate aldıkları bir husus olarak görünmektedir.

\section{a-Emanet}

Emanetin ne olduğu konusunda pek çok görüş vardır. Bunlar içerisinde itaat, ${ }^{1}$ akıl, ${ }^{2}$ kâinatta Allah'a ve O’nu birliğine delalet eden şeyler, ${ }^{3}$ hilafet, ${ }^{4}$ dinî yükümlülükler (farzlar ve hadler), ${ }^{5}$ elest bezminde alınan mîsâk, ${ }^{6}$ marifetullah, ${ }^{7}$ namaz, ${ }^{8}$ insanların birbirlerine bıraktıkları türden emanet, ${ }^{9}$ insanın bedeni, ${ }^{10}$ erkek ve kadının avret mahalli ve bunun korunması (iffet), ${ }^{11}$ tevhit, ${ }^{12}$ ilahî isimlerin ve sıfatların tecellisii ${ }^{13}$ gibi görüşler öne çıkmak-

1 Mukātil b. Süleyman, Tefsîr, thk. Ahmed Ferîd, Beyrut, 2003, III, 57; Taberî, İbn Cerîr, Câmiu'l-beyân an te’vîli’lKur'an, thk. Abdülmuhsin et-Türkî, Kahire, 2001, XIX, 196; Nehhâs, Ebu Ca'fer, Me'âni'l-Kur'an, thk. M. Ali es-Sabûnî, Mekke, 1989, V, 385; Mâverdî, Ali b. Muhammed b. Habib, en-Nüket ve'l-uyûn, Beyrut, ts, IV, 428; Zemahşerî, Carullah Mahmud b. Ömer, el-Keşşâf, thk. A. Abdülmevcud- Muhammed Muavvıd, Riyad, 1998, V, 102; İbn Âşûr, Muhammed Tâhir, et-Tahrîr ve’t-tenvîr, Tunus, 1984, XXII, 126.

2 Kādî Beydâvî, Envârü't-tenzîl, İstanbul, ts, II, 254; Şirbînî, Muhammed b. Ahmed, Tefsirü's-siraci'l-münir, Beyrut, ts, III, 340; İbn Âşûr, et-Tahrîr ve't-tenvîr, XXII, 127.

3 Mâverdî, en-Nüket ve'l-uyûn, IV, 429; Tûsî, Ebû Ca’fer, et-Tibyân fî tefsiri'l-Kur'an, thk. A. Habib el-Âmilî, Beyrut, ts, VIII, 367.

4 İbn Kuteybe, Tefsîru ğarîbi'l-Kur'an, thk. es-Seyyid Ahmed Sakr, Beyrut, 1978, s. 353; İbnü’l-Cevzî, Ebu'lFerec Abdurrahman b. Ali b. Muhammed, Zâdü'l-mesîr fî 'ilmi't-tefsîr, Beyrut, 1984, VI, 428;Konevi, İsmail b. Muhammed, Haşiye 'ala tefsiri'l-Beydavi, nşr. Abdullah M. Ömer, Beyrut, 2001, XV, 434; İbn Âşûr, et-Tahrîr ve'ttenvîr, XXII, 126.

5 Taberî, Câmiü'l-beyân, XIX, 197-201; Mâtürîdî, Ebu Mansûr Muhammed, Te’vîlâtu'l-Kur'an, thk. Ali Haydar Ulusoy, İstanbul, 2008, XI, 393; Nehhâs, Me'âni'l-Kur'an, V, 384; Mâverdî, en-Nüket ve'l-uyûn, IV, 428; Râzî, Fahreddin, Mefâtîhu'l-ğayb, Beyrut, 1981, XXV, 236; İbn Âşûr, et-Tahrîr ve't-tenvîr, XXII, 126.

6 Konevî, Hâşiye, XV, 431; İbn Âşûr, et-Tahrîr ve’t-tenvîr, XXII, 127.

7 Âlûsî, Rûhu'l-maânî, Beyrut, ts, XXII, 102.

8 Âlûsî, R̂̂hu'l-maânî, XXII, 102

9 Taberî, Câmiü'l-beyân, XIX, 201-202; Mâverdî, en-Nüket ve'l-uyûn, IV, 429; İbn Âşûr, et-Tahrîr ve't-tenvîr, XXII, 127.

10 Şevkânî, Fethü'l-kadîr, Beyrut, ts, IV, 308.

11 Taberî, Câmiü'l-beyân, XIX, 200; Mâverdî, en-Nüket ve’l-uyûn, IV, 428; İbn Kesîr, İmadüddin Ebu'l-Fidâ, Tefsîru'lKur'ani'l-azîm, thk. M. es-Seyyid Muhammed vd, Kahire, 2000, XI, 251.

12 Mâtürîdî, Te’vîlât, XI, 393; Ebû Bekir İbnü'l-Arabî, Ahkâmu'l-Kur'ân, thk. Rıza Ferec, Beyrut, 2012, III, 508; Kuşeyri, Abdülkerim, Letâifü'l-işârât, nşr. A. Hasan Abdurrahman, Beyrut, 2007, III, 46; İbn Âşûr, et-Tahrîr ve'ttenvîr, XXII, 127.

13 Âlûsî, Rûhu'l-maânî, XXII, 99; İbn Âşûr, et-Tahrîr ve't-tenvîr, XXII, 127. 
tadır. İbn Âşûr (ö. 1973) bu görüşleri beş ana başlık altında toplar. Buna göre emanetin şer’i yükümlülükler ve ibadet-itaat gibi anlamlara geldiği söyleyen görüşler birinci grubu; itikat ve inanç konuları ile ilgili olduğunu ifade eden görüşler ikinci grubu; ihanetin zıddı anlamındaki emanet anlamını vurgulayanlar üçüncü grubu, akıl görüşü dördüncü grubu, hilafet görüşü ise beşinci grubu oluşturmaktadır. İbn Âşûr’a göre insana yüklendiği ifade edilen emanetin muhakkak insan fıtratında yerleşik bir özellik olması gerekir, çünkü aksi durumda vahye muhatap olmayan ve şeriattan haberdar olmayan kimselerin bu emaneti yüklenmemiş olduğu sonucu çıkar. ${ }^{14}$ Âlûsî (ö. 1127/1715) emanet kelimesini insanın bedeni, avret mahalli gibi uzuvlar şeklinde yorumlamanın iltifata değer olmadığını kaydetmekte, bu doğrultudaki rivayetlerin, sahih kabul edilmeleri durumunda bile bu anlamlara delalet etmeyeceğini söylemektedir. ${ }^{15}$ Bir diğer görüş Süddîden (ö. 127/744) nakledilir; buna göre emanet, Âdem Aleyhisselamın, oğlu Habil'i diğer oğlu Kābil’e emanet etmesi, onun da bu emanete hryanet etmesidir. ${ }^{16}$ Şevkânî (ö. 1250/1834) bu yorumu şiddetle eleştirmekte, dilsel açıdan hiçbir tutarlılığg olmadığ 1 gibi rivayet ve mantık açısından da zayıf olduğunu ifade etmektedir. ${ }^{17}$

Rivayetlerde emanetin Allah tarafından insana yüklenen mükellefiyetler olduğu yönünde ifadeler mevcuttur. Ancak bu hususlar rivayetlerde tekil olarak ifade edilmiş, kiminde namazdan, kiminde abdestten, zekâttan, Ramazan orucundan, kiminde diğer ibadetlerden söz edilmiştir. ${ }^{18}$ Yine itaat, sevap-günah gibi kavramlar da rivayetlerde emanetin anlamı çerçevesinde zikredilmektedir. ${ }^{19}$ Buna karşılık akıl, hilafet, mîsâk, marifetullah vb. görüşler, sözü edilen emanetin sadece insanda bulunan, kâinattaki diğer varlıklarda bulunmayan özellikler olması açısından bu kelimeye yüklenmiş anlamlar olarak değerlendirilebilir.

\section{b-Emanetin Yüklenilmesi (Hamlü'l-emâne)}

Arz edilen bu emanetin insan tarafından yüklenmesine (haml) karşılık dağların, göklerin ve yerin bundan kaçınmaları ve ürpermeleri (ibâ ve işfâk) iki farklı şekilde anlaşılmıştır. İlkine göre bu ifadeler zâhir (kelimeden ilk etapta anlaşılan ve baskın olan) anlam üzeredirler; yani haml kelimesi yüklenmek, üstlenmek anlamına, ibâ ve işfâk kelimeleri ise yüklenmekten kaçınmak, korkmak gibi anlamlara gelmektedir. Buna göre Allah emaneti yere, göklere ve dağlara arz etmiş, fakat onlar bu emaneti yüklenmekten çekinmişler, bu yüzden yüklenmek istememişler, insan ise (bir tür cüretkârlık göstererek, haddini bilmeyerek) yüklenmiştir. ${ }^{20} \mathrm{Bu}$ durumda emanetin sadece insanda bulunan, cansız varlıklarda bulunmayan bir hususiyet olması gerekmektedir. ${ }^{21}$ Çünkü bu yoruma göre cansız varlıklar (yer, gökler ve dağlar) bu emaneti yüklenmek istememiş, dolayısıyla yüklenmemiş olmaktadırlar. Bunun neticesinde ise emanetin akıl, şer'i mükellefiyetler, mîsâk, hilafet seçeneklerinden birine

14 İbn Âșûr, et-Tahrîr ve't-tenvîr, XXII, 127.

15 Âlûsî, Rûhu'l-maânî, XXII, 97.

16 Taberî, Câmiu'l-beyân, XIX, 203; Mâverdî, en-Nüket ve'l-uyûn, IV, 428; Kurtubî, el-Câmiu li-ahkâmi'l-Kur'an, thk. Abdürrezzak el-Mehdi, Beyrut, 2007, XIV, 226; Semerkandî, Ebu'l-Leys, Bahru'l-'ulûm, thk. A. Muhammed Muavvıd- A.Ahmed Abdülmevcud, Beyrut, 1993, III, 63.

17 Şevkânî, Fethü'l-kadîr, IV, 308-309.

18 bk. Sem'ânî, Ebu'l-Muzaffer, Tefsîrü'l-Kur'an, thk. Yâsir b. İbrahim- Ğuneym b. Abbas, Riyad, 1997, IV, 313.

19 Taberî, Câmiu'l-beyân, XIX, 200-201.

20 Mâverdî, en-Nüket ve’l-uyûn, IV, 429; İbnü'l-Cevzî, Zâdü'l-mesîr, VI, 428.

21 Bu hususu Gazâlî de ifade etmiştir. bk. Gazâlî, Ebû Hâmid, İhyâu ulûmi’d-dîn, Beyrut, ts, III, 14. 
göre anlamlandırılması gerekmektedir. Çünkü emaneti (örneğin) itaat olarak tanımladıktan sonra haml, ibâ ve işfâk kelimelerine bu ilk görüşteki anlamı vermek, cansız varlıkların Allah'a itaat etme özelliğine sahip olmadıkları anlamına gelecektir. Oysa bu ayetin tefsirinde müfessirlerin sıklıkla atıf yaptıkları gibi Kur'an (örneğin Ra'd 13/15; Hacc 22/18), canlı cansız bütün varlıkların Allah’a kulluk/itaat ettiklerini çeşitli şekillerde ifade etmektedir. İkinci görüşe göre ise emanetin yüklenilmesi (hamlüll-emâne) emanete ihanet etmek, yani emanet olarak verilen şeyin hakkını yerine getirmemek anlamına gelir. ${ }^{22}$ Çünkü bir şeyi yüklenmiş olmak, onun insanın sırtında bir yük, görev olarak mevcudiyetinin devamını ima etmektedir. Bu ise söz konusu görevin insanın uhdesinden henüz kalkmamış olduğu, yani yerine getirilmediği anlamına gelir. Bu anlam üzerinden düşünüldüğg̈nde, göklerin, yerin ve dağların emaneti yüklenmekten kaçınmaları, emaneti hakkıyla îfâ etmeleri anlamına gelecektir. Dolayısıyla göklerin, yerin ve dağların ibâ ve işfâk tavrı içinde olmaları, emaneti üstlenmeyi kabul etmeyip geri çevirmek şeklinde değil, onun hakkını vermek, gereğini bihakkın yapmak şeklinde anlaşılacaktır. Görüleceği üzere bu görüşte haml kelimesine ilk etapta akla gelen baskın (zâhir) anlamın tam aksi bir istikamette mana verilmiştir. Bu tercihin delillendirilmesi Zemahşerî tarafından yapılmıştır ve yazımızın ana konusunu teşkil edecektir.

\section{c- Mecaz-Temsil Tartışması}

Emanet kelimesine hangi anlam verilirse verilisin, adına emanet denilen bir şeyin göklere, yere ve dağlara (cansız varlıklara) sunulması, bu sunumun keyfiyeti ihtilaf konusu olmuştur. Acaba bu sunum gerçekten yaşanmış mıdır yoksa burada mecazi bir anlatım mı söz konusudur? İlk görüşe göre bu hadise gerçekten yaşanmıştır ve Allah bu cansız varlıklara o esnada bu sunumu anlayabilecekleri akıl gücü vermiş, onlar da bu akıl sayesinde, kendilerine yapılan bu teklifi değerlendirmiş ve kabul etmemeyi tercih etmişlerdir. ${ }^{23}$ Daha sonra Allah onlardan bu aklı geri almıştır. Bu görüşte olanlar söz konusu arzın lüzûm (zorunluluk) içeren, yani zorunlu olarak kabul edilmesi gereken bir arz değil, muhataba kabul ve ret seçeneği sunmak şeklinde bir arz olduğunu ifade etmişlerdir. ${ }^{24}$ Çünkü Allah’̉n herhangi bir varlığa belli bir görevi lüzûm içerecek şekilde arz etmesine rağmen o varlığın bundan kaçınmış olduğunu düşünmek, ilahî kudret açısından muhaldir. Bu izah Hasan-1 Basrînnin (ö. 110/728) görüşü olarak da nakledilmiştir. ${ }^{25}$

İkinci görüşe göre burada temsîlî bir anlatım söz konusudur. Anlatılmak istenen; emanet mükellefiyetinin dağların, göklerin ve yerin dahi taşımaktan çekinecekleri kadar ağır bir sorumluluk olduğu düşüncesidir. ${ }^{26}$ Zemahşerînin savunduğu bu görüşün delilleri ilerde genişçe ele alınacaktır. Yine bu görüşle aynı minvalde olmak üzere, cansız varlıkların bu teklifi kabul etmeyecek (edemeyecek) şekilde yaratılmış oldukları, dolayısıyla buradaki sunumun (arz), yaratılışın keyfiyetine delalet eden bir ifade olduğu söylenmiştir. Bu görüşte olanlara

22 bk. Zeccâc, Me’âni'l-Kur'an, thk. Abdülcelil Şelebi, Beyrut, 1988, IV, 238; Mâtürîdî, Te’vîlât, XI, 395; Nehhâs, Méâni'l-Kur'an, V, 386; Zemahşerî, Keşşâf, V, 102.

23 Nehhâs, Me'âni'l-Kur'an, V, 386; Sem'ânî, Tefsîrü'l-Kur'an, IV, 313; Kuşeyri, Letâifü'l-işârât, III, 46, Âlûsî, Rûhu'lmaânî̀, XXII, 97.

24 Mâtürîdî, Te’vîlât, XI, 394-395; İbnü’l-Cevzî, Zâdü'l-mesîr, VI, 428.

25 Semerkandi, Bahru'l-'ulûm, III, 63.

26 Zemahşerî, Keş̧̧âf, V, 102-103; Tabersî, Mecmau'l-beyân, VIII, 142. 
göre bu arz, arz-ı hilkat'tir, yani Allah bu varlıkları sözü edilen emaneti taşıyamayacak bir yaratılışta yaratmıştır. Anlatılmak istenen husus budur. ${ }^{27}$

Üçüncü bir görüşe göre ise âyetteki 'ale’s-semâvâti ve’l-arzi ve'l-cibâli [göklere, yere ve dağlara] ifadesi 'alâ ehli's-semâvâti ve'l-arzi ve'l-cibâli [göklerin, yerin ve dağların ehline, halkına] anlamında olup ehl kelimesi hazf edilmiştir. ${ }^{28} \mathrm{Bu} e h l$ ifadesi ile de genellikle meleklerin kast edildiği söylenmiştir. ${ }^{29}$ Âlûsî bu görüşün Mu'tezile'den [Ebû Ali] el-Cübbâî̀ye atfedildiğini belirtmekte ve "kayda değer bir görüş değildir" [leyse bi-şey ${ }^{\text {sin }}$ ] şeklinde değerlendirmektedir. ${ }^{30}$

\section{d- "el-İnsân" Kelimesinin Kapsamı}

Âyette "çok zalim" (zalûm) ve "çok cahil" (cehûl) olarak nitelenen el-İnsân kelimesi bir görüşe göre bütün insanları kapsayan genel bir ifadedir. ${ }^{31}$ Bu Sa'leb’in (ö. 291/903) görüşü olarak nakledilir. Bir diğer görüşe göre ise el-İnsan'dan maksat Hz. Âdem'dir. Bu görüş Hasan-1 Basrîye atfedilmiştir. ${ }^{32}$ İbnü’l-Cevzî (ö. 597/1200) -ilginç bir şekilde- bunun cumhurun (çoğunluğun) görüşü olduğunu kaydetmektedir. ${ }^{33}$ İbnü’l-Cevzînin bu kaydı ilginçtir, çünkü eğer hadise yaratılışın başlangıcında gerçekleşmiş ise, o zaman Hz. Âdem'in şahsında bütün insanlıktan söz ediliyor olması gerekir. Diğer seçenekler söz konusu ise, o zaman Hz.

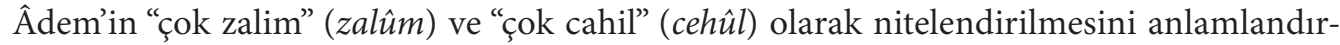
mak zorlaşmaktadır. ${ }^{34}$ Diğer taraftan Zeccâc, Nehhâs (ö. 338/949), Sem’ânî (ö. 428/1096) ve İbnü'l-Cevzî gibi müfessirler Hasan-1 Basrî̀ye, el-İnsan kelimesi ile kâfir ve münafik kimselerin kast edildiği şeklindeki görüşü de atfetmiştir. ${ }^{35}$ Zeccâc’in naklinde Hasan-1 Basrî bu görüşünü, "kâfir ve münafık emaneti yüklenmiş, fakat gereğini yerine getirmemişlerdir" şeklinde delillendirmektedir. Bu da, Hasan-1 Basrîye ait olan (asıl) görüşün bu olduğu düşüncesini güçlendirmektedir. Bu teyidin ardından Zeccâc aynı görüşü, devamında gelen âyetlerde münafiklardan ve kâfirlerden söz edilmesine ve itaat ehli olan peygamberler ve sıddîklara "çok zalim” (zalûm) ve "çok cahil” (cehûl) demenin mümkün olmayışına değinerek gerekçelendirmektedir. ${ }^{36}$ Bir başka görüşe göre ise el-İnsan'dan maksat Kābil'dir. İbnü’l-Cevzî bu görüşü Süddîye (ö. 127/744) atfetmektedir. ${ }^{37}$

\section{II- Zemahşeri'nin Yorumu ve Argümantasyonu}

Öncelikle “Zemahşerînin yorumu” ifadesinin bu yorumun ilk kez Zemahşerî tarafından yapıldığı anlamına gelmediğini belirtmek gerekmektedir. Çünkü bu yorum Zeccâc,

27 Mâtürîdî, Te’vîlât, XI, 394; Tûsî, et-Tibyân, VIII, 367.

28 Nehhâs, Me'âni'l-Kur'an, V, 383; Tabersî, Fadl b. Hasan, Mecmau'l-beyân, thk. S. Haşim el-Mahallâtî, Beyrut, 2009, VIII, 141; Sem'ânî, Tefsîrül-Kur'an, IV, 313; Kuşeyri, Letâifüll-işârât, III, 46.

29 Mâverdî, en-Nüket ve'l-uyûn, IV, 429; İbnü'l-Cevzî, Zâdü'l-mesîr, VI, 428; Semerkandi, Bahru'l-’ulûm, III, 63; Tûsî, et-Tibyân, VIII, 367.

30 Âlûsî, Rûhu'l-maânî, XXII, 97.

31 Mâverdî, en-Nüket ve'l-uyûn, IV, 430.

32 Mâverdî, en-Nüket ve'l-uyûn, IV, 430.

33 İbnü'l-Cevzî, Zâdü'l-mesîr, VI, 429.

34 bk. Tabersî, Mecmau'l-beyân, VIII, 142.

35 Zeccâc, Me'âni'l-Kur'an, IV, 238; Nehhâs, Me'âni'l-Kur'an, V, 387; Sem'ânî, Tefsîrül-Kur'an, IV, 313; İbnü'l-Cevzî, Zâdü'l-mesîr, VI, 428.

36 Zeccâc, Me'âni'l-Kur'an, IV, 238.

37 İbnü'l-Cevzî, Zâdü'l-mesîr, VI, 429. 
Mâtürîdî, Nehhâs, Tûsî (ö. 460/1067) gibi Zemahşerî öncesinde yaşamış müfessirler tarafından kaydedildiği gibi Zemahşerî ile çağdaş olan Tabersî (ö. 548/1153) tarafından da kaydedilmiştir. Tûsî bu yorumu Mu'tezile'den Ebu'l-Kāsım el-Belhî̀ye (ö. 319/913) atfederek, ${ }^{38}$ Tabersî ise (en azından temsil/mecaz görüşünü, bu görüşün gerekçelerini ve âyetteki haml kelimesine "ihanet" anlamını vermeyi) Ebû Ali el-Cübbâîye (ö. 303/915) atfederek ${ }^{39}$ nakletmektedir. Bu da söz konusu yorumun bütün bir tefsir literatüründe olduğu gibi Mu’tezile tefsir geleneğinde de Zemahşerî öncesinde açık ve güçlü bir mevcudiyetinin bulunduğunu gösterir. Diğer taraftan Zemahşerî, birazdan “Zemahşerînin yorumu” olarak aktaracağımız yorumu tek seçenek olarak sunmayıp ikinci bir görüş daha vermekte ve bu görüşlerden herhangi birini diğerine tercih ettiğini ihsas edecek hiçbir kayda yer vermemektedir. Bahse konu olan bu yorumun belki Zemahşerî ile birlikte şöhret ve meşruiyet bulmuş olduğu söylenebilir ve ancak bu açıdan bunun “Zemahşerînnin yorumu” olduğu ifade edilebilir.

\section{a- Emanet: itaat}

Zemahşerî tarafından belirli ölçüde delillendirilmiş olan bu görüşü, doğrudan Keşşâf metindeki pasajlar üzerinden değerlendireceğiz. Öncelikle Zemahşerî, âyetin metin içi bağlamını öne çıkaracak şekilde, bir önceki âyette Allah'a ve peygambere itaat etme konusunun zikredildiğine dikkat çekmekte ve devamında gelen "emanet ayeti" ile "Allah'a ve peygambere itaat etme"nin öneminin vurgulandı̆̆ını ifade etmektedir;

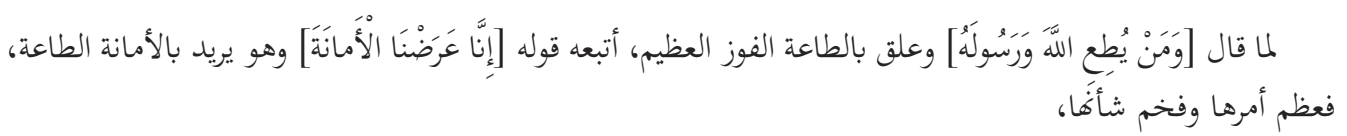

Hak Teâlâ önce "her kim Allah'a ve Resûlüne itaat ederse [büyük başarıya nail olur]" buyurup "büyük başarı"yı "itaat” ile ilişkilendirmiş olduğu için, bunun hemen devamında "biz emaneti... arz ettik" buyurmuştur ki, bu emanet ile "itaat"i kast etmektedir. Böylelikle emanetin önemini ta’zim etmiş, durumunu yüceltmiş olmaktadır. ${ }^{40}$

Böylece Zemahşerî ilk etapta emanet kelimesine itaat anlamının verilmesini, siyak-sibak ilişkisi çerçevesinde delillendirmiş olmaktadır. Haddizatında kelimeye bu anlamın verilmesi rivayetlerle de gerekçelendirilebilir. Dolayısıyla Zemahşerînin bu noktadaki argümantasyonunun yeterince güçlü olduğunu söylemek mümkündür. Çünkü gerçekten de emanet kelimesine "itaat" anlamı verildiğinde, 72. âyette konu olan emanetin göklere, yere ve dağlara arz edilmesi meselesi, 69-70. âyetlerdeki konu ile güçlü bir şekilde irtibatlandırılmış olacaktır. 69-70. âyetlerde surenin başında da işaret edilen bir konuya değinilmektedir. Konu Hz. Peygamber'in Zeyneb bt. Cahş ile evliliği çerçevesinde gelişen hadiselerdir. Bilindiği gibi bu evlilik esnasında münafıklar ve yahudiler, Zeyneb bt. Cahş’ın daha önce Hz. Peygamber'in azatlı kölesi ve ardından evlatlığı olan Zeyd b. Harise ile evli olmasından yola çıkarak "Muhammed oğlunun eski eşiyle evleniyor” şeklinde bir yaygara koparmışlar, böylece müminleri etkilemek istemişlerdir. Surenin 40. âyetinde [Muhammed aranızdan hiçbir erkeğin babası değildir] denilirken, onun Zeyd b. Harise’nin gerçek babası olmadığı, dolayısıyla münafıkların ve yahudilerin "Muhammed oğlunun eski eşiyle evleniyor" şeklindeki yaygaralarına

38 Tûsî, et-Tibyân, VIII, 367.

39 Tabersî, Mecmau'l-beyân, VIII, 141.

40 Zemahşerî, Keşşâf, V, 102. 
itibar edilmemesi gerektiği ifade edilmiştir. Taberî, 40. âyetteki vurgunun bu olduğunu çok açık bir şekilde ifade etmektedir. ${ }^{41}$

İşte bu yaygara Medine’de bazı müslümanları da etkilemiş olmalıdır ki, sûrede müminlere sitemkâr bir dille hitap edilmekte, ["Allah ve Resûlü bir konuda belli bir hüküm/karar verdikten sonra hiçbir mümin erkek ve kadının o konuda başka bir tercihte bulunması söz konusu olamaz" (Ahzâb 33/36)] denilmektedir. Bu ifadelerde Zeynep bt. Cahş ve kardeşinin kast edildiği müfessirler tarafından ifade edilmiştir. ${ }^{42}$ Bu çerçevede 69-71. âyetlerde şöyle denilmektedir;

Ey İman edenler! Vaktiyle Musa'ya eziyet eden kimseler gibi olmayın. Bakın, Allah Musa'yı onların söylediklerinden temize çıkarmıştı. Kaldı ki Musa, Allah katında çok değerli idi. Ey İman edenler! Allah’tan korkun ve doğru söz söyleyin ki Allah da sizin işlerinizi ıslah etsin ve günahlarınız bağışlasın. Her kim Allahia ve Resulüne itaat ederse, büyük bir başarıya nail olmuş demektir.

$\mathrm{Bu}$ ifadelerin hemen ardından emanetin göklere, yere, dağlara arz edilmesinden söz edilmesi, bu emanetin Allah’a ve peygambere itaat etmekle bir ilgisinin olduğunu düşündürmektedir. Bu da, emanet kelimesine verilen anlamlar içerisinden "itaat” seçeneğinin tercih edilmesini yeterli ölçüde delillendirmiş olmaktadır.

\section{b- Birinci Yorum}

Zemahşerî bunun ardından âyetin devamındaki ifadelerin iki türlü yorumlanabileceğini söylemekte ve ilk yorumu vermektedir;

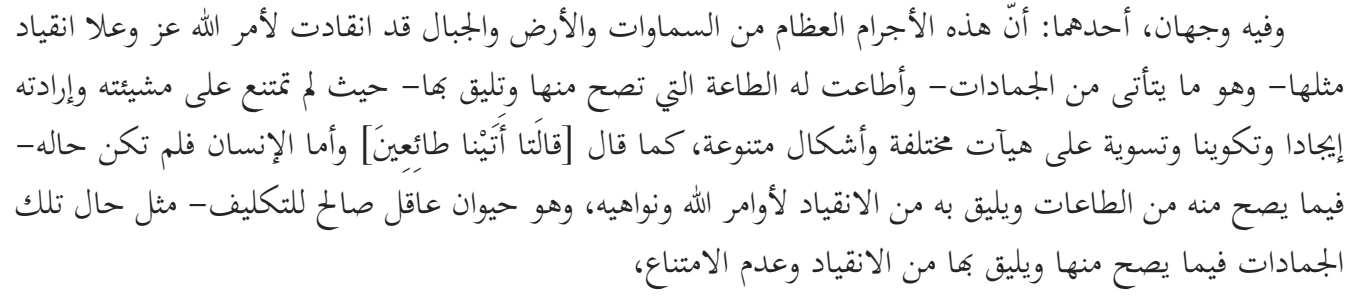

Burada iki yorum vardır. İlki şöyledir: Şu devasa fiziksel hacme sahip olan gökler, yer ve dağlar, kendileri gibi olan varlıkların Allah'a boyun eğme biçimlerince- cansız varlıklardan sadır olacak şekilde- Allah’a boyun eğmişler, kendilerinden sadır olması mümkün olacak tarzda ve kendilerine yaraşır şekilde O’na itaat etmişlerdir. Nitekim bu varlıklar Allah'ın kendilerini farklı şekillerde ve çeşitli biçimlerde yaratması, var etmesi ve düzenlemesi konusundaki irade ve meşîetine karşı çıkmamışlar, bundan imtina etmemişlerdir. Bu husus, [“(yer ve gök) 'itaatkâr olarak geldik' dediler” (Fussilet 41/11)] ayetinde de ifade edilmiştir. İnsanın ise -akıl sahibi ve mükellefiyete uygun bir canlı olduğu halde- kendisinden sadır olması mümkün olan itaati gösterme

41 Taberî, Câmiu'l-beyân, XIX, 121.

42 bk.Taberî, Câmiu'l-beyân, XIX, 112-113; Râzî, Mefâtîhu'l-ğayb, XXV, 212. 
ve kendisine yaraşacak şekilde ilahî emirlere ve yasaklara boyun eğme konusundaki durumu, bu cansız varlıkların kendilerinden sadır olacak ve kendilerine yaraşacak şekilde Allah'a boyun eğme ve imtina etmeme konusundaki durumları gibi olmamıştır. ${ }^{43}$

Buna göre âyette kâinattaki cansız varlıkların (göklerin, yerin ve dağların) kendi varlık tarzlarına uygun bir biçimde Allah'a itaat etmekte oldukları, O’na karşı gelmedikleri, fakat insanın akıl sahibi bir canlı olarak bu durumda olmadığı, Allah'a itaat konusunda kusurlu olduğu ifade edilmiş olmaktadır. Oysa âyetteki ifadelerin zahir [düz/doğrudan] anlamı böyle değildir. Zahir anlama göre emanet yere, göklere ve dağlara sunulmuş, onlar bu emaneti yüklenmekten çekinmişler, insan ise çekinmeyip yüklenmiştir. Yani Zemahşerînnin burada ifade ettiği anlam, âyetten ilk okunuşta akla gelen anlamın dışındadır. Dolayısıyla âyetten bu anlama ulaşabilmek için öncelikle buradaki $\operatorname{arz}$ (sunum) hadisesinin ve cansız varlıkların bu teklifi kabul etmemelerinin (ibâ ve işfâk) mecaz olduğunun ortaya konulması, daha sonra da haml kelimesinin yüklenmek değil, gereğini yapmamak, emanete hiyanet etmek anlamına geldiğinin kanıtlanması gerekmektedir. Bir diğer önemli sorun ise, emanet kelimesi her ne kadar itaat anlamına geliyor olsa da, âyette neden doğrudan “itaat” kelimesinin değil de "emanet" kelimesinin kullanıldığının izah edilmesidir. Böylece âyetin tefsirinin tam bu noktasında üç temel soru ortaya çıkmaktadır;

a) $\operatorname{Arz}$ (sunum) hadisesinin ve cansız varlıkların bu teklifi kabul etmemelerinin (ibâ ve işfâk) mecaza hamledilmesinin gerekçesi nedir?

b) Haml kelimesine, zahir anlamı terk ederek, "emanete hıyanet etmek" anlaminın verilmesinin gerekçesi nedir?

c) Âyette itaat kelimesinin yerine emanet kelimesinin kullanılmış olmasının sebebi nedir?

Bu sorulara verilen cevaplar Zemahşerî tefsirinin gücünü gösterdiği gibi zayıf noktalarını da göstermektedir. Diğer taraftan bu soruların Zemahşerî öncesi tefsir geleneğinde bu denli açık bir şekilde sorulmamış (bu meselelerin konu edilmemiş) olması, Zemahşerînin özgün ve güçlü yanını göstermekte, sorulara verilen cevapların tartışmaya açık olması ise yapılan yorumun zayıf yönlerini teşkil etmektedir. Elbette bu sorular metinde bizim ifade ettiğimiz şekilde açıkça sorulmamakta, ancak cevaplandırılmak suretiyle zımnen sorulmuş olmaktadır. Zemahşerînnin ilk iki soruya ilişkin cevabı sarih bir şekilde anlaşılır olduğu halde, üçüncü soru ve bu soruya verilen cevap metinde açık olmayıp belirli bir yorum dolayımıyla anlaşılabilir niteliktedir. Yani aşağıdaki ifadenin böyle bir soruya cevaben söylenmiş olup olmadığı, yorum gerektirmeyecek açıklıkta değildir;

$$
\text { والمراد بالأمانة: الطاعة، لأفا لازمة الوجود، كما أن الأمانة لازمة الأداء. }
$$

Emanet ile kast edilen “itaat”tir, çünkü itaat varlık itibariyle zorunluluk arz eder (lâzimetü’l-vücĥd), emanet ise edâ (yerine getirilme) açısından zorunluluk (lâzimetü'l-edâ) arz eder. ${ }^{44}$ 
Emanet ile itaat kelimeleri arasında kurulan bu benzerlik, bu kelimelerden birinin diğerinin yerine kullanılmış olmasının gerekçesi gibi görünmektedir. Çünkü emanet ile itaat arasında burada ifade edilen benzerliğin olması, emanet kelimesinin itaat anlamına geldiğini kanıtlayacak bir argüman olamaz. Zira eğer bu benzerlik böyle bir kanıt teşkil etseydi, Arap dilinde uzmanlıkları konusunda kuşku bulunmayan büyük müfessirlerin ve onlardan önce tabiîn devri âlimlerinin bu kelimeye başka anlamlar vermiş olmalarını izah etmek mümkün olmazdı. Dolayısıyla Zemahşerînin buradaki ifadesi emanet kelimesine itaat anlamının verilmesinin gerekçesi değil, -emanet kelimesine itaat anlamının verilmesi metin içi siyak üzerinden delillendirildikten sonra-, âyette neden doğrudan itaat kelimesinin değil de, emanet kelimesinin tercih edilmiş olduğunun gerekçesi olmalıdır. Eğer bu yorumumuz doğru ise, yani burada Zemahşerî âyette doğrudan itaat kelimesinin kullanılmayıp onun yerine emanet kelimesinin kullanılmış olmasını delillendirmek istiyorsa, ortaya koyduğu bu argüman yeterli görünmemektedir. Diğer taraftan bu yorumumuzun yanlış olması durumunda, yani Zemahşerînin bu ifadesinin emanet kelimesinin itaat anlamına geldiğini delillendirmeye matuf olduğunu düşünmemiz halinde de, söz konusu delillendirme sorunludur. Çünkü belli durumlarda belli kelimelerin kullanılması, kelimeler arası ilişkiler ya da kelimeler ile varlıklar arasındaki ilişkiler üzerinden değil, ancak dilin toplumsal boyutu üzerinden gerekçelendirilebilir. ${ }^{45}$ Diğer deyişle kelimeler ile anlamlar arasındaki ilişki mantıksal değil, rastlantısaldır. ${ }^{46}$ Yani hangi kelimenin hangi durumda kullanılacağı, kelime ile durum arasında mantıksal bağlantı kurularak verilen bir karar değil, dil içerisinde o tür durumlarda o kelimenin kullanılıp kullanılmadığına bakılarak verilebilecek bir karardır. Çünkü biz belli bir durumu ifade etmek için bir kelime kullandığımız zaman, muhatabımızın o kelimeden tam da o durumu anlayacağını varsayarız. Bu da, o kelimenin o durumu ifade etmek üzere kullanılması konusunda önceden sağlanmış toplumsal bir mutabakatın var olmasını gerektirir. Aksi durumda muhatabımızdan söylediğimiz sözü mevcut dilbilgisi üzerinden anlamasını değil, kullandığımız kelime ile o kelimeyi ilişkilendirdiğimiz durum arasındaki mantıksal bağlantıyı tam da bizim kurduğumuz gibi kurmasını beklemiş oluruz. Takdir edileceği üzere böyle bir beklenti, iletişim imkânını tehdit edecek boyutlar içerir. Haddizatında (Zemahșerînin de içerisinde yer aldığı) Mu'tezile geleneğinde dil-varlık ilişkisinin toplumsal boyutu vurgulanmış, dillerin vaz’nnın tevkîfî (ilahî) değil, istılâhî (toplumsal uzlaşıma dayalı) olduğu açıkça ifade edilmiş ve savunulmuştur. ${ }^{47}$ Buna ilgili tartışmalarda muvâzaâ (toplumsal uylaşım) denmektedir. ${ }^{48}$ Bu açıdan bakıldığında bir fikir ve tasavvur olarak "emanet" ile "itaat" arasında Zemahşerînin ifade ettiği lüzûm ilişkisinin bulunması, bunları ifade etmek için kullanılan kelimelerin birbirinin yerine kullanılmasını gerektirmez. En azından böyle bir kullanım için yeterli şartı sağlamaz. Böyle bir kullanımı en güçlü

45 bk. Ferdinand De Saussure, Genel Dilbilim Dersleri, Çev. Berke Vardar, İstanbul, 1998, s. 109 vd; Taylan Altuğ, Dile Gelen Felsefe, İstanbul, 2008, s. 204, 218 vd; Türkan Fırıncı Orman, "Jacques Derrida Düşüncesinde "Dil”, Kilikya Felsefe Dergisi, (1), 2015, s. 61-81.

$46 \mathrm{Bu}$ rastlantısallık, zorunsuzluk anlamındadır.

47 İlgili tartışmanın geniş özeti için bk. Suyûtî, el-Müzhir fi 'ulumi'l-luğati ve enva’iha, thk. Fuâd Ali Mansûr, Beyrut, 2009,I, 12 vd. Mutezile içerisinde farklı görüşte olanlar da vardır. Örneğin Ebu’l-Hüseyin el-Basrîye (ö. 436/1044) göre kelamın (sözün) tanımında muvazaa şart değildir, çünkü dilciler kelamı, mühmel ve müsta’mel olarak ikiye taksim etmişlerdir. Bu da, mühmel olan, yani belli bir anlamın karşıllı̆̆ olmayan kelime ya da seslerin de kelam cümlesinden sayılmasını gerektirir. bk. Ebu'l-Hüseyin el-Basrî, el-Mu'temed fì usûli'l-fikh, nşr, Halil el-Meyyis, Beyrut, 2005, I, 10.

48 Kādî Abdülcebbâr, el-Muğnî fi ebvabit-tevhidi ve'l-'adl, thk. Mahmud Kāsım, Kahire, ts, V, 160 vd. 
şekilde gerekçelendirecek olan argüman, vahyin indiği toplumsal vasat içerisinde emanet kelimesinin itaat anlamında kullanılıyor olduğunu ispat etmektir. Diğer deyişle Cahiliye şiirinden, o döneme ait deyişlerden ya da Hz. Peygamber'in veya sahabenin başka vesilelerle emanet kelimesini itaat anlamında kullandıklarına dair örneklerden hareketle argümanı kurmak daha sağlıklı olacaktır. Ne var ki Zemahşerî argümanı bu şekilde kurmamaktadır. $\mathrm{Bu}$ durum, elde böyle bir argümanın mevcut olmadığ anlamına gelebilir. Neticede biz, Cahiliye devri Araplarının ve Kur’an’ın nüzûl döneminde yaşayan insanların, emanet kelimesinden itaat anlamını anlayıp anlamadıkları konusunda somut bir veriye sahip değiliz. $\mathrm{Bu}$ da, diğer mantıksal argümanların, ne kadar güçlü olurlarsa olsunlar, yeterli olmayacağ 1 anlamına gelmektedir.

Yukarıdaki sorulardan ikincisini cevaplama, yani haml kelimesine emanete hiyanet manasının verilmesinin gerekçesini ortaya koyma sadedinde Zemahşerî şöyle demektedir;

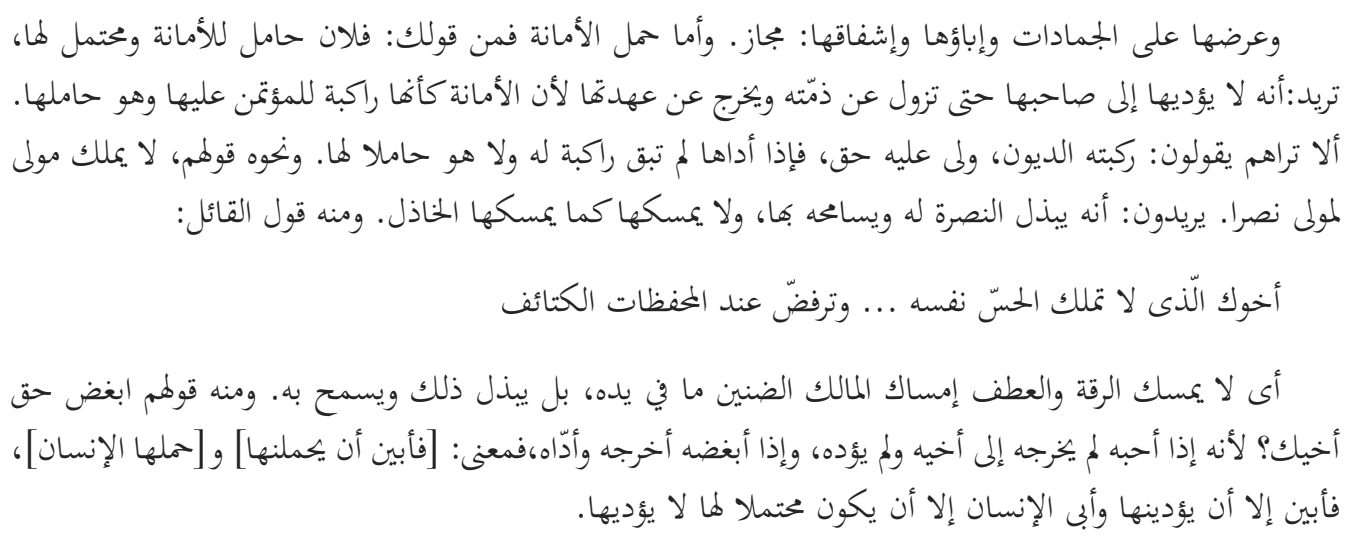

Emanetin cansız varlıklara sunulması ( $a r z)$ ve onların da bundan kaçınmaları ve çekinmeleri (ibâ ve işfâk) mecazdır. Emanetin yüklenmesi (hamlü'lemane) ise "falan kimse emaneti yüklenmiştir", "onu yük edinmiştir" şeklindeki ifadelerine benzer ki, sen bu ifadeleri kullandığında kişinin emaneti teslim (edâ) etmediğini, bu yüzden de emanetin kişinin zimmetinden çıkmamış olduğunu ve kişinin de o emanetin sorumluluğundan kurtulamamış olduğunu kast edersin. Çünkü bu durumda emanet sanki kendisine emanet verilen kimsenin sırtında bir binici gibi, emanet verilen kimse ise onun taşıyııısı gibidir. Nitekim Arapların rakibethüd-düyûn [borçlar sırtına bindi] ve lî 'aleyhi hakk ${ }^{u n}$ [Onun üzerinde bana ait bir hak var] şeklindeki ifadeleri de böyledir. Kişi emaneti edâ ettiği zaman artık emanet onun sırtında binici olarak kalmaz ve o da emanetin yüklenicisi olmaz. (Fiilin bu şekilde kullanı$\mathrm{m}$ ) Arapların "Dost dosta yardıma malik değildir" [lâ yemlikü mevlen li-mevlen nasr $\left.{ }^{a n}\right]$ ifadesinde de söz konusudur. Bu ifadede Araplar, dostun dosta yardımı elinden geldiğince sarf edeceğini, perişan vaziyetteki kimsenin yaptığı gibi yardımını dostundan sakınıp elinde tutmayacağını ifade etmek isterler. Şairin şu ifadeleri de bu kabildendir; 
Ehûke'llezi lâ temliku'l-hisse nefsuhu ve terfaddu 'inde'l-muhfizâtill-ketâifu [Kardeşin dediğin hissine (merhametine) malik olmayan... ve dara düştügünde kırgınlıkları dağılıp gidendir.]

Yani (kardeş dediğin kimse) şefkat ve merhametini tıpkı cimri bir mal sahibinin elindeki malı sıkı sıkıya tuttuğu gibi tutmaz, aksine onu sarf eder, bolca harcar. Yine Arapların "kardeşinin hakkına buğz et” şeklindeki ifadeleri de buna benzemektedir. Çünkü insan kardeşinin hakkını severse onu çıkarıp da kardeşine vermez, ama o hakka buğz ederse çıkarıp verir ve eda eder.

Dolayısıyla âyetteki fe-ebeyne en yehmilneha [onu yüklenmekten kaçındılar] ve hameleha'l-insân [insan onu yüklendi] ifadelerinin manası; "onlar (cansız varlıklar) emaneti eda etmekten başka her şeyden kaçındılar, insan ise emaneti sırtında yük etmekten ve onu eda etmemekten başka her şeyden kaçındı” şeklindedir. ${ }^{49}$

İşte Zemahşerînin meşhur görüşü ve delillendirmesi böyledir. Baş taraftaki [Emanetin cansız varlıklara sunulması (arz) ve onların da bundan kaçınmaları ve çekinmeleri ( $i b a \hat{~ v e ~}$ işfâk) mecazdır] ifadesi, ilerde konu edilecek olan ve yukarıdaki sıralamamızda ilk sıraya koyduğumuz sorunun cevabı çerçevesindedir. Aslında bu ifadelerin mecaza hamledilmesi bu yorum (birinci yorum) açısından zorunluluk teşkil etmemektedir. Dolayısıyla burada böyle bir tespitin yapılması, metin için insicam açısından sorunlu görünmektedir. Zira bu yorum, söz konusu ifadeleri mecaza hamletmeden de yapılabilir. Oysa birazdan göreceğimiz ikinci yorumun kabul edilebilmesi için arz, ibâ ve işfâk kelimelerinin mecaza hamledilmesi zorunludur. Zaten -bu nedenle olsa gerek- Zemahşerî burada sadece bu tespiti yapmakla yetinmekte, delillendirmeyi ise ikinci yorum çerçevesinde yapmaktadır. Dolayısıyla bu konuyu ikinci yorum çerçevesinde ele alacağız. Devamındaki metne yakından bakıldığında, Zemahşerînin temel iddiasının "haml kelimesinin emaneti yüklenme anlamına gelmediği, aksine dolaylı yoldan hıyanet anlamına geldiği” şeklinde olduğu görülmektedir. Bu iddiayı desteklemek üzere Zemahşerî Arap dilinde bu şekilde dolaylı anlamda kullanılan başka fiillerin bulunduğunu ifade etmekte, örnek olarak "Dost dosta yardıma malik değildir" [lâ yemlikü mevlen $l i-m e v l^{e n}$ nasr ${ }^{a n}$ ] ifadesinde geçen yemliku fiilini ve şiirde geçen "Kardeşin dediğin hissine (merhametine) malik olmayandır” [Ehûke'llezi lâ temliku'l-hisse nefsuhu] beytindeki temliku fiilini göstermektedir. Bu örneklerdeki yemliku/temliku fiili zahir mana itibariyle malik olmak, sahip olmak anlamına gelse de, dolaylı olarak "sahip çıkamamak, tutamamak, bolca vermek, bahş etmek” gibi anlamlarda kullanılmıştır. Zemahşerîye göre âyetteki haml fiili de işte bu temliku/yemliku fiili gibi dolaylı bir anlama sahiptir. Dikkatle bakıldığında Zemahşerînnin bu delillendirmesi, haml fiiline verdiği anlamı mümkün kılmakla birlikte, yeterli açıklıkta kanıtlamamaktadır. Çünkü Zemahşerînin gösterdiği deliller bize, haml fiilinin de yemliku/temliku gibi kullanılmış olduğunu kesin olarak göstermemektedir. Burada haml kelimesine dolaylı anlam vermenin imkânı kanıtlanmış olmakla birlikte vukuu kanıtlanmış değildir. Diğer deyişle bazı kelimelerin bu şekilde dolaylı anlama gelebileceği kanıtlanmış, bunun Arap dilinde yaygın ve bilinen bir kullanım olduğu gösterilmiş olsa da, haml kelimesinin bunlardan biri olduğunu ve bu kelimenin âyetteki kullanımın da

49 Zemahşerî, Keşşâf, V, 102-103. 
bu yönde olduğunu gösteren bir delil bulunmamaktadır. Eğer Zemahşerî doğrudan haml kelimesinin bu şekilde dolaylı bir anlamda kullanıldığında dair Cahiliye şiirinden ya da o döneme dair deyişlerden bir örnek verebilseydi, istediği kanıtlamayı daha güçlü bir şekilde başarmış olurdu. Çünkü böyle bir delil bize, Kur'an’n indiği dönemin Arap toplumunun emanet kelimesini bu anlamda kullanmakta olduğunu, dolayssiyla ihanet/hiyanet "anlamı" ile haml "kelimesi" arasında ilişki kurulmasına dair bir muvazaanın (toplumsal uylaşımın) bulunduğunu gösterirdi. İște bu nokta Zemahşerînin argümantasyonundaki en önemli boşluğu teşkil etmektedir. Tam da bu noktada Derveze (ö. 1984) haml kelimesine hıyanet manası vermenin hem dil açısından hem de bu kökten türeyen kelimelerin Kur'an'daki genel kullanımı açısından problemli olduğuna işaret etmektedir. ${ }^{50}$ Ayrıca Derveze'ye göre haml kelimesini bu şekilde yorumlamak bütün bir insan cinsinin zalim ve cahil olarak nitelenmesini gerektirecektir. Ancak bize göre Derveze bu tespitinde yeterince dikkatli değildir. Çünkü haml kelimesinin Kur'an'daki genel kullanımında Zemahşerînin yorumuna imkân tanıyacak unsurlar bulunmaktadır. Her ne kadar Zemahşerî bunları zikretmemiş olsa da, örneğin Zeccâc haml kelimesinin günah taşımak anlamında kullanıldığını ifade etmekte ve

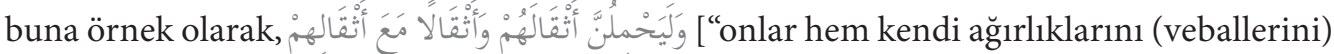
hem de kendilerininki ile birlikte başka ağırlıkları da yükleneceklerdir" (Ankebût 29/13)] ayetindeki kullanımı göstermektedir. ${ }^{51}$ Mâtürî̀î de bu görüşte olanların Kur'an'da haml kelimesinin daima günah, hata gibi şeylerin yüklenilmesi anlamında kullandığına işaret

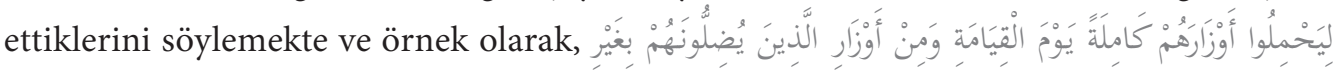
["Kıyamet gününde kendi günahlarını tam olarak taşımaları ve bilgisizce saptırmakta óldukları kimselerin günahlarından da bir kısmını yüklenmeleri için...” (Nahl 16/25)]

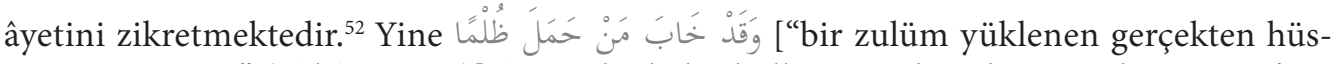
rana uğramıştır" (Tâhâ 20/111)] âyetinde de bu kullanım çok açıktır. Bu da Derveze'nin Kur'an’ın genel kullanımı hakkındaki tespitinin titiz olmadığını göstermektedir. Üstelik Derveze’nin iddiasının aksine, haml kelimesine Zemahşerînin verdiği anlamı vermekle el-İnsân lafżnı umuma hamletmek arasında zorunlu bir ilişki bulunmamaktadır. Ancak bu durum, (Derveze'nin tespitine yönelik bu tenkitlerimiz) Zemahşerînin haml kelimesine verdiği anlamın Kur'an'daki bütün kullanımlar için geçerli olduğunu da göstermez. Örne-

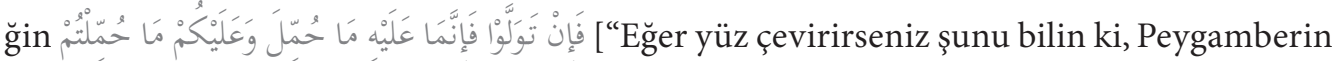
sorumluluğu kendíne yüklenén, sizin sorumluğunuz da size yüklenendir.” (Nur 24/54)] âyetinde haml kelimesi sorumluluk yüklenme anlamında kullanılmıştır. Haddizatında bu âyetlere baktığımızda haml kelimesinin anlamını belirleyen şeyin, bu kelimeye muzâf ya da mef'ûl olan unsur olduğunu söylemek mümkündür. Diğer deyişle "zulmü hamletmek" ya da "vizr'i (günahı) hamletmek" denildiği zaman bunun günahkâr olmak, zulüm işlemek gibi bir anlama geldiğini derhal anlayabiliriz, ama "emaneti hamletmek" denildiği zaman bunun emaneti yüklenmek mi yoksa emanete hiyanet etmek mi olduğunu belirlemek kolay değildir. Dolayısıyla incelediğimiz âyette haml kelimesinin bu iki anlamdan hangisine geldiğini, bu kelimenin Kur'an'daki diğer kullanımları üzerinden tespit etmek mümkün değildir. Bu yüzden de bu âyette haml kelimesinin hangi anlamda kullanıldığını

50 Derveze, Muhammed İzzet, et-Tefsîru'l-hadîs, Tunus, 2008, VII, 429-430.

51 Zeccâc, Meâni'l-Kur'an, IV, 238.

52 Mâtürîdî, Te’vîlât, XI, 395. 
belirleyecek olan şey, cahiliye Araplarının emanet kelimesi ile birlikte kullanıldığı zaman bu kelimeden, yani hamlü'l-emâne kalıbından ne anladıklarının tespit edilmesidir. Bu tespit yapılamadığı zaman (ki Zemahşerî gibi dilbilim uzmanı bir müfessir dahi bu tespiti yapmış değildir) geriye kelimenin zahir, baskın anlamından hareket etme seçeneği kalmaktadır. Bu durumda da haml kelimesine hıyanet anlamı değil, yüklenme anlamını vermek daha güçlü bir ihtimal olarak görünmektedir. Belki de Zemahşerînin bu görüşü tek görüş olarak vermeyip ikinci görüşü de arz etmesinin ve aralarında herhangi bir tercihte bulunmamasının sebebi de budur.

Diğer taraftan tefsir geleneğinde haml kelimesinin hıyanet manasına geldiğini şiir üzerinden delillendirme teșebbüsü de mevcuttur. Hem Ebû Hayyân (ö. 745/1345) ve Alûsînin ${ }^{53}$ Zeccâc'a atfettikleri ${ }^{54}$ bir yorumda hem de dördüncü yüzyılın önemli dilbilim âlimlerinden Ezherînnin (ö. 370/980) Tehzîbu'l-lüğâs'sında haml kelimesinin emanete ihanet etmek anlamına geldiğini delillendirmek üzere, cahiliye şairlerinden Beyhes el-'Uzrînin ${ }^{55}$ aşă̆ıdaki beyti verilmiştir;

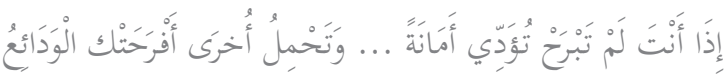

Sen (böyle) devamlı olarak bir emaneti eda edip de

bir başkasını yüklenirsen, emanetler belini büker (ağırlaşır)

Ezherîye göre beyitteki ve tahmilu uhrâ ifadesi [bir başka emanete hryanet edersen] anlamına gelmektedir. Yine Ezherî̀ye göre beytin sonundaki efrahatke’l-vedâiu ifadesi de [hiyanet ettiğin emanetler belini büker] anlamına gelmekte, dolayısıyla da ve tahmilu uhrâ ifadesinin [bir başka emanete hıyanet edersen] anlamına geldiğini göstermektedir. ${ }^{56} \mathrm{Ne}$ var ki Ebû Hayyân beyitteki ve tahmilu uhrâ ifadesinin [bir başka emanete hryanet edersen] anlamına değil, [bir diğer emaneti yüklenirsen] anlamına geldiğini söyleyerek, bu beytin haml kelimesinin hıyanet anlamında kullanılışına dair açık bir delil (nass) olmadığını söylemektedir. ${ }^{57}$ Kaldı ki Ezherî̀nin iddiasının aksine, beytin sonundaki "emanetler belini büker" ifadesi ve tahmilu uhrâ ifadesinin [bir başka emanete hıyanet edersen] anlamına geldiğini göstermek için yeterli görünmemektedir. Zira beyti, "bir emaneti edâ eder etmez hemen bir başka emaneti yüklenirsen, sürekli olarak emanet sorumluluğu taşımak belini büker" şeklinde anlamak pekâlâ mümkündür, dolayısıyla Ebû Hayyân’ın itirazı oldukça yerinde görünmektedir. Zemahşerî de muhtemelen Ebû Hayyan’ın tespit ettiği bu ihtimalin farkında olduğu için bu beyit ile istişhatta bulunmamıştır. Fakat bu durumda Zemahşerînnin argümantasyonundaki boşluk kapatılamamış, yani hamlü'l-emâne kelimesine "emanete hıyanet etme" anlamını vermek yeterince gerekçelendirilememiş olmaktadır. Belki de bu nedenle Âlûsî (her ne kadar hamlü'l-emâne kelimesine "emanete hıyanet etme" anlamının verilmesi

53 Âlûsî, Rûhu'l-maânî, XXII, 99.

54 Aslında Ebû Hayyân’ın bu beyti Zeccâc'a atfettiğini Âlûsî söylemektedir, ancak Ebû Hayyân tefsirinde beyit Zeccâc'a değil, İbn İshak'a atfedilmektedir. bk. Ebû Hayyân, Muhammed b. Yusuf, el-Bahru'l-muhît, thk. A. Ahmed Abdlmevcudvd, Beyrut, 1993, VII, 244.

55 Beyhes el-'Uzrî hakkında çok az bilgi vardır. bk. Âmidi, Ebu'l-Kāsım el-Hasen b. Bişr, el-Mü'telif ve’l-muhtelif fi esmâişşşuarâi ve kenâhüm ve elkābihim ve ensâbihim ve ba'zi şiłrihim, thk. Fritz Krenkow, Beyrut, 1991, s. 79.

56 Ezherî, Ebû Mansur Muhammed b. Ahmed, Tehzîbu'l-lüğâa, thk. M. Avad, Beyrut, 2001, V, 61

57 Ebû Hayyân, el-Bahru'l-muhît, VII, 244. 
konusunda herhangi bir değerlendirme yapmasa da) bu yorumun geneli hakkında, "zayıfllğ 1 açıktır, rivayetlerde de bunu destekleyen bir șey göremiyoruz" ifadelerini kullanmaktadır. ${ }^{58}$

\section{c- İkinci Yorum}

İlk görüşteki bu argümantasyon boşluğu nedeniyle olsa gerek, Zemahşerî herhangi bir değerlendirme yapmadan doğrudan ikinci görüşe geçmekte ve bu görüşü şu şekilde sunmaktadır;

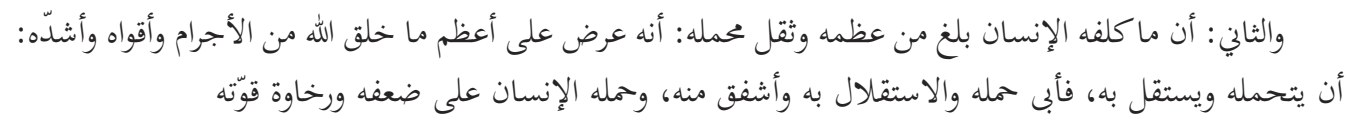

İnsana yüklenmiş olan (mükellefiyet) öylesine muazzamdır ve ağırdır ki Allah’n yaratmış olduğu mahlûkat içerisinden en büyük, en kuvvetli ve şedîd olanına dahî bu mükellefiyeti müstakil olarak yüklenip taşıması arz edilse bunun yüklenip müstakil olarak taşımaktan kaçınır, bundan çekinir. İnsan ise zayıfllğına ve gücünün azlığına rağmen bunu üstlenmiştir. ${ }^{59}$

Bu görüş, daha önce de ifade ettiğimiz üzere, başlangıçta emanet kelimesine “itaat" anlamı verdikten sonra ayetin geri kalan kısmı hakkında ortaya çıkan iki ihtimalden biri olarak ifade edilmiştir. Keşşâf şârihi Trybî (ö. 743/1342) bunu açıkça ifade etmektedir. ${ }^{60}$ Dolayısıyla bu pasajdaki mâ küllifehu'l-insan [insana yüklenen mükellefiyet] ifadesini "itaat" olarak anlamak mümkündür. İşte bu yorumda emanetin sunulmasını (arz) ve cansız varlıkların bundan kaçınmasını (ibâ ve işfâk) mecaza hamletmeyi zorunlu kılan nokta da burasıdır. Çünkü insana yüklenen mükellefiyetin itaat olduğunu kabul ettiğimizde, bu itaat mükellefiyetinin sunulması karşısında cansız varlıkların bundan kaçınmalarını mecazi bir anlatım olarak değil de gerçek bir hadise olarak düşünmek mümkün görünmemektedir. Böyle bir kaçınma, Allah'a itaatten kaçınma anlamına gelecek ve devamında cansız varlıkların itaat hali içinde olmadıkları gibi bir neticeyi doğuracaktır. Bu nedenle de bu arz, ibâ ve işfâk' mecaza hamledilmesi gerekmektedir. Böylelikle ortada gerçek bir sunumun ve gerçek bir kaçınmanın olmadığı; aksine bu ifadelerde insana yüklenen itaat mükellefiyetinin dağlar, gökler ve yer gibi devasa cirme sahip varlıklar tarafından dahi taşınamayacak denli ağır olduğunun anlatıldığı sonucu çıkarılacaktır. Buna karşılık ilk yorum dikkate alındığında bu ifadeleri mecaza hamletmek zorunlu olmamaktadır. Çünkü o yoruma göre zaten cansız varlıkların emaneti reddetmeleri, bundan kaçınmaları söz konusu değildir. Aksine hamlülemane tabirine verilen hıyanet anlamının gereği olarak o yoruma göre, cansız varlıklar emanetin gereğini bihakkın yerine getirmişler, yani bizzat kendi varlık tarzlarının gerektirdiği ve bu tarz içinde mümkün olacak şekilde [fî̀ mâ yesıhhu minhâ ve yelîku bihâ mine’linkiyâd ve 'ademi'l-imtinâ'] itaat etmişlerdir. İnsan ise kendi varlık tarzının gerektirdiği ve bu tarz içinde mümkün olacak şekilde itaat etmemiş̧ir. Dolayısıyla buradaki arzın arz-ı hilkat olduğu, yani Allah’n o varlıkları bu şekilde yarattığı düşünüldüğünde, ayrıca bir mecaza hamletme sorunu kalmamaktadır. Fakat Zemahşerî metninde sorun olan nokta, bu arz,

58 Âlûsî, Rûhu'l-maânî, XXII, 99.

59 Zemahşerî, Keşşâf, V, 103.

60 Tiybî, el-Hüseyn b. Abdullah, Fütûhu'l-ğayb, thk. Ö. Hasan el-Kıyyam, Abu Dabi, 2013, XII, 490. 
ibâ ve işfâk'ın mecaza hamledilmesine ilişkin tespiti ikinci yorum kapsamında değil, birinci yorum kapsamında yapılmış olmasıdır. Oysa -yukarıda ifade ettiğimiz gibi- arz, $i b \hat{a}$ ve işfâk’ın mecaza hamledilmesi birinci yorum kabul edildiğinde değil, ikinci yorum kabul edildiğinde zorunlu olmaktadır. Ancak yine de Zemahşerî ilk yorum çerçevesinde k1saca yapmış olduğu bu tespitin gerekçelendirmesini burada, yani ikinci yorum kapsamında yapmaktadır. Bu da söz konusu tespit ve gerekçelendirmenin bu yorumla (ikinci yorumla) ilişkili olduğunun Zemahşerî tarafında da kabul edildiğini düşünmemize imkân vermektedir. Ancak bu durumda da mecaza ilişkin bu tespitin ilk görüş esnasında yapılmış olması, bir sorun olarak kalmaktadır. Her halükarda Zemahşerî mecaza hamletmenin gerekçesini bu yorum çerçevesinde yapmakta ve şöyle demektedir;

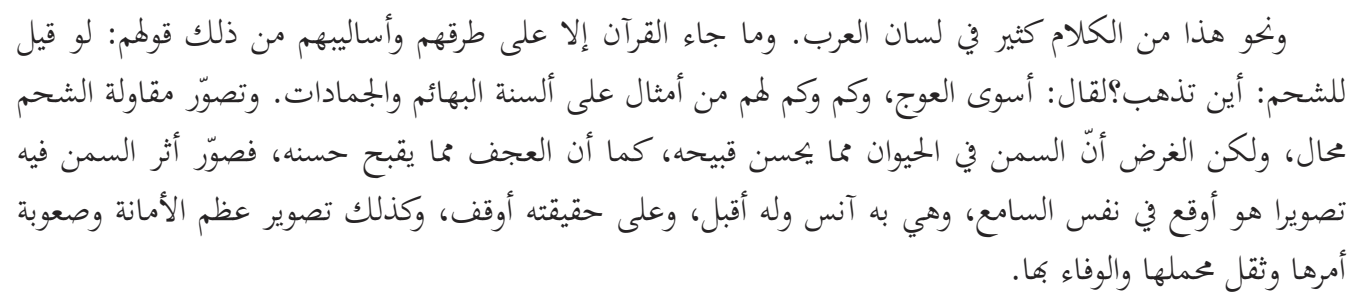

Bu tür ifadeler Arap dilinde çoktur. Zaten Kur'an da onların ifade tarzlarına ve üsluplarına göre gelmiştir. Örneğin lev kıyle lişsşahmi eyne tezheb le-kāle üsevvi'l-'ivec [Yağa sorulsa nereye gidiyorsun diye, eğrilikleri düzetmeye der] şeklindeki sözleri böyledir. Bundan başka cansız varlıkların ve hayvanların dilinden daha nice nice misaller vardır. Burada yağ ile bir karşılıklı konuşmanın yapıldığını tasavvur etmek muhaldir. Fakat anlatılmak istenen şey hayvanlarda besili olmanın çirkinliği örten, cılızlığın ise güzelliği örtüp çirkinleştiren bir özellik olduğudur. Bu itibarla besili olmanın hayvandaki neticesi (yağın hayvanı güzelleştirmesi), dinleyen kişinin aklında daha etkili şekilde yer edecek (evka'), akıl tarafından daha kolay anlaşılacak, (ânes) daha kolay kabul edilecek (ekbel), hakikatine daha bir vakıf olacak (evkaf) şekilde tasvir edilmiştir. İşte âyette de emanetin büyüklüğü, taşınmasının zorluğu ve vefâ ile yerine getirilmesinin çetinliği tasvir edilmiştir. ${ }^{61}$

$\mathrm{Bu}$ argümantasyonun dilbilim açısından yeterince güçlü olduğu açıktır. Ancak dikkat çekici olan husus, "yağ ile bir karşılıklı konuşmanın yapıldığını tasavvur etmek muhaldir" cümlesinde kendisini göstermektedir. Hatırlanacağı üzere Nehhâs, Semânî ve Kuşeyrî gibi müfessirler Allah'ın bu cansız varlıklara o esnada bu sunumu anlayabilecekleri bir akıl gücü verdiğini, onların bu akıl sayesinde, kendilerine yapılan teklifi değerlendirdiklerini ve kabul etmemeyi tercih ettiklerini ifade etmişlerdir. ${ }^{62}$ Her ne kadar Zemahşerî teferruata girmemiş olsa da, bu mesele esas itibariyle kelamda illiyet, nedensellik, tabiat, tecviz gibi kavramlar çerçevesinde tartışılan konularla ilgilidir. ${ }^{63}$ Ancak yine de hem tabiat görüşünü kabul et-

61 Zemahşerî, Keşşâf, V, 103.

62 Nehhâs, Me'âni'l-Kur'an, V, 386; Sem'ânî, Tefsîrü'l-Kur'an, IV, 313; Kuşeyri, Letâifü'l-işârât, III, 46.

63 Konuyla ilgili olarak bk. Kutluer, İlhan, “İlliyet”, DİA, XXII, 120-121; Yavuz, Yusuf Şevki, “İlliyet” DİA, XXII, 121 123; a.mlf, “İmam Matürîdî̉nin Tabiat ve İlliyete Bakışı” Büyük Türk Bilgini İmam Matürîdî ve Matürîdîlik içinde, İstanbul, 2012, ss. 54-64. 
meyen Eşarîi kelamına mensup âlimlerin hem de sebeplerin varlığını ve nesnelerin belli tabiatlarda yaratıldığını belirtmesine rağmen sebeplerin ve tabiatların sonuçlar üzerindeki etkisini zayıflatıcı bir yaklaşımı benimseyen Matürî̀î ${ }^{64}$ kelamına mensup âlimlerin de bu ifadeleri mecaza hamlettikleri vakidir. Bizzat Mâtürîdînnin kendi yorumu buna en açık örnektir. Bu da, söz konusu yorum farkının bir yönüyle kelamdaki illiyet, nedensellik, tabiat, tecviz gibi konularla ilgili olsa da bütünüyle bu tartışmalar tarafından domine edilmediğini gösterir.

Zemahşerî son olarak $a r z$, ibâ ve işfâk'ın mecaza hamledilmesine ilişkin tespite yöneltilebilecek muhtemel bir itirazı dile getirip cevaplamaktadır. Bu itirazda Arap dilinde temsilin bilinen iki şey arasında yapıldı ̆̆ , fakat ayette cansız varlıklara emanetin arz edilmesinin bilinebilir ve mümkün daire içerisinde olmadığı, dolayısıyla bunun temsile konu olmasının uygun olmayacağı ifade edilmiştir. Buna verilen cevapta ise her ne kadar cansız varlıklara emanetin sunulması özü itibariyle muhal olsa da bunun zihnen tahayyül edilebileceği vurgulanmış ve zihinde tahayyül etme açısından varsayımsal durumlar (mefrûzât) ile diş dünyada gerçekleşmiş durumlar (muhakkakāt) arasında bir fark olmadığı belirtilmiştir.

\section{Sonuç}

Emanet âyeti olarak bilinen Ahzab 33/72-73. âyetler surenin iç bağlamı çerçevesinde düşünüldüğünde Hz. Peygamber'in Zeyneb bt. Cahş ile evlenmesi hadisesi karşısında münafıkların ve yahudilerin çıkardıkları yaygaraları ve bu yaygaralardan etkilenen müminleri Allah'a ve peygambere itaat etmeye, bu ağır sorumluluğun gereğini yapmaya teşvik ediyor görünmektedir. Zemahşerî başta olmak üzere, emanet kelimesine itaat anlamın veren müfessirlerin yorumları bu değerlendirmeyi güçlendirmektedir. Bununla beraber bu âyet üzerinde tefsir geleneğinde farklı yorumlar da yapılmıştır. Bu yorumlarda emanet kelimesinin tam olarak hangi anlama işaret ettiği tartışıldığ gibi cansız varlıklara emanetin sunulmasının gerçek bir hadisenin anlatımı mı yoksa mecaz mı olduğu da tartışılmıştır. Zemahşerînnin yorumu, emanet kelimesinin itaat anlamında olduğu yönündedir ve bunu metin içi bağlam ile teyit etmektedir. Ancak emanet kelimesine itaat anlamı verildikten sonra âyetin geri kalan kısmı, yani bu itaat mükellefiyetinin dağlara, göklere ve yere sunulmasının ve onların ibâ ve işfâk tavrı içinde olmalarının ne anlama geldiği konusunda Zemahşerî iki farklı yorum vermekte ve ikisinden hangisini tercih ettiğine dair açık bir ifade kullanmamaktadır. Diğer taraftan ilk görüş olarak verdiği yorum daha önce Zeccâc, Mâtürîdî, Nehhâs, Tûsî gibi müfessirler tarafından kaydedildiği gibi Zemahşerî ile çağdaş olan Tabersî tarafından da kaydedilmiştir. Bu da Zemahşerînin yorumu olarak bilinen bu yorumun aslında tefsir geleneğinde Zemahşerî öncesinde de bilindiğini göstermektedir. Ancak Zemahşerînin bu yorumu gerekçelendirme konusunda önemli bir rolünün bulunduğu da açıktır. Bununla beraber Zemahşerînnin argümantasyonu kusursuz değildir. Bu argümantasyonda hamlülemane kalıbına haml kelimesinin zahir anlamından hareketle "emaneti yüklenme" anlamı vermek yerine bu zahir anlamı terk edip "hıyanet" anlamı vermek yeterince delillendirilememiştir. Çünkü Keşşaf metninde en nihayetinde yemliku/temliku fiillerinin buradakine benzer şekilde zahir anlamın tam tersi istikamette kullanıldığı şiir üzerinden kanıtlanmış, fakat haml kelimesinin bu şekilde kullanıldığına dair bir örnek verilmemiştir. Bu ise haml

64 Yavuz, İmam Matürîdînin Tabiat ve İlliyete Bakışı, s. 62. 
kelimesinin zahir anlamın tam tersi istikamette anlamlandırılmasını mümkün kılıyor olmakla beraber, âyetteki kullanımın bu yönde olduğunu tam olarak tespit etmeye yetmemektedir. Çünkü bu argüman, haml kelimesinin bu şekilde kullanılışının vukuunu değil, imkânını göstermektedir. Bu da argümanı kusursuz olmaktan çıkarmaktadır.

\section{Kaynaklar}

Altuğ, Taylan, Dile Gelen Felsefe, İstanbul, 2008.

Âlûsî, Ebu'l-Fazl Şihabuddîn Mahmud, Rûhu'l-maânî, Beyrut, ts.

Âmidi, Ebu'l-Kāsım el-Hasen b. Bişr, el-Mü’telif ve'l-muhtelif fi esmâiş̧-şuarâi ve kenâhüm ve elkābihim ve ensâbihim ve ba'zi şirihim, thk. FritzKrenkow, Beyrut, 1991.

Basrî, Ebu’l-Hüseyin, el-Mu’temed fî usûli'l-fikh, nşr, Halil el-Meyyis, Beyrut, 2005.

Derveze, Muhammed İzzet, et-Tefsîru'l-hadîs, Tunus, 2008.

Ferdinand De Saussure, Genel Dilbilim Dersleri, Çev. Berke Vardar, İstanbul, 1998.

Fırıncı Orman, Türkan, “Jacques Derrida Düşüncesinde "Dil”, Kilikya Felsefe Dergisi, (1), 2015, s. 61-81.

Gazâlî, Ebu Hamid, İhyâu ulûmi'd-dîn, Beyrut, ts (Daru’l-Ma'rife).

İbn Âşûr, Muhammed Tâhir, et-Tahrîr ve't-tenvîr, Tunus, 1984.

İbn Kesîr, İmadüddin Ebu'l-Fidâ, Tefsîru'l-Kur'ani'l-azîm, thk. M. es-Seyyid Muhammed vd, Kahire, 2000.

İbn Kuteybe, Tefsîru ğarîbi'l-Kur'an, thk. es-Seyyid Ahmed Sakr, Beyrut, 1978.

İbnü’l-Arabî, Ebû Bekir, Ahkâmu'l-Kur'ân, thk. Riza Ferec, Beyrut, 2012.

İbnü'l-Cevzî, Ebu'l-Ferec Abdurrahman b. Ali b. Muhammed, Zâdü'l-mesîr fî 'ilmi't-tefsîr, Beyrut, 1984.

Kādî Abdülcebbâr, el-Muğnî fî ebvâbi't-tevhîd ve'l-'adl, (el-Firakğayru'l-İslâmiyye) thk. M. Kāsım, Kahire, ts.

Kādî Beydâvî, Envârü't-tenzîl, İstanbul, ts.

Konevi, İsmail b. Muhammed, Haşiye 'ala tefsiri'l-Beydavi, nşr. Abdullah M. Ömer, Beyrut, 2001.

Kurtubi, el-Câmiu li-ahkâmi’l-Kur'an, thk. Abdürrezzak el-Mehdi, Beyrut, 2007.

Kuşeyri, Abdülkerim, Letâifü̉l-işârât, nşr. A. Hasan Abdurrahman, Beyrut, 2007.

Kutluer, İlhan, “İlliyet”, DİA, XXII, 120-121.

Mâtürîdî, Ebu Mansûr Muhammed, Te’vîlâtu'l-Kur'an, thk. Ali Haydar Ulusoy, İstanbul, 2008.

Mâverdî, Ebu'l-Hasen Ali b. Muhammed b. Habib, en-Nüket ve'l-uyûn, Beyrut, ts.

Mukātil b. Süleyman, TefsîruMukātil b. Süleyman, thk. Ahmed Ferîd, Beyrut, 2003. 
Nehhâs, Ebu Ca’fer, Me’âni'l-Kur'an, thk. M. Ali es-Sabûnî, Mekke, 1989.

Râzî, Fahreddin, Mefâtîhu'l-ğgayb, Beyrut, 1981.

Sem'ânî, Ebu'l-Muzaffer Mansûr b. Muhammed, Tefsîrü'l-Kur'an, thk. Yâsir b. İbrahim- Guneym b. Abbas, Riyad, 1997.

Semerkandi, Ebu'l-Leys, Bahru'l-’ulûm, thk. A. Muhammed Muavvıd- Adil Ahmed Abdülmevcud, Beyrut, 1993.

Suyûtî, Celalüddin, el-Müzhir fî 'ulûmi'l-luğati ve envâ'ihâ, thk. Fuâd Ali Mansûr, Beyrut, 2009.

Şevkânî, Fethü'l-kadîr, Beyrut, ts (Alemü'l-kütüb).

Şirbînî, Muhammed b. Ahmed, Tefsirü's-siracill-münir, Beyrut, ts, (Alemü'l-kütüb).

Taberî, İbn Cerîr, Câmiu'l-beyân an te’vîli’l-Kur'an, thk. Abdülmuhsin et-Türkî, Kahire, 2001.

Tabersî, Fadl b. Hasan, Mecmau’l-beyân, thk. S. Haşim el-Mahallâtî, Beyrut, 2009.

Tiybî, Şerefüddin el-Hüseyn b. Abdullah, Fütûhu'l-ğgybfi'l-keşf'an kınâi'r-rayb, thk. Ö. Hasan el-Kiyyam, Abu Dabi, 2013.

Tûsî, Ebû Ca'fer, et-Tibyân fî tefsiri'l-Kur'an, thk. A. Habib el-Âmilî, Beyrut, ts, (Dâru ihyâi'ttürâsi'l-'arabî).

Yavuz, Yusuf Şevki, “İlliyet” DİA, XXII, 121-123.

----, “İmam Matürîdînin Tabiat ve İlliyete Bakışı” Büyük Türk Bilgini İmam Matürîdî ve Matürîdîlik içinde, İstanbul, 2012, ss. 54-64.

Zeccâc, Ebû İshâk, Me'âni’l-Kur'an, thk. Abdülcelil Şelebi, Beyrut, 1988.

Zemahşerî, Carullah Mahmud b. Ömer, el-Keşşâf, thk. A. Ahmed Abdülmevcud-A. Muhammed Muavvıd, Riyad, 1998. 